\title{
Fremskritt i dialektisk atferdsterapi for suicidal ungdom
}

\author{
Ved A lec L M iller og Jennifer $\mathrm{H}$ artstein
}

\begin{abstract}
Dialektisk atferdsterapi har vist seg effektiv i behandling av utvalgte grupper voksne personer med kronisk tendens til suicidal atferd. Ved Montefiore Medical Center i New York har en gruppe klinikere nå videreutviklet denne behandlingsmodellen og tilpasset den for tenåringer. Så langt er behandlingsresultatene lovende.
\end{abstract}

I U SA dør flere ungdommer av selvmord enn av alle naturlige dødsårsaker til sammen. Selvmord er rangert som den tredje hyppigste dødsårsaken hos unge mellom 15 og 24 år, etter ulykker og drap ( $\mathrm{N}$ ational $\mathrm{C}$ enter for $\mathrm{H}$ ealth Statistics 1996). Selvmord er den sjette hyppigste dødsårsaken hos barn mellom 5 og 14 år (A A C A P 1998). Til tross for at den faktiske selvmordsraten blant ungdom er relativt lav - ca 13,8 per 100000 (svarende til ca 2000 selvmord i året) (N CHS 1996) - har det vært en sterk økning i raten i løpet av de siste femti år. I følge Peters et al. (1998) økte selvmordsraten blant amerikansk ungdom i alderen 15-19 år med 245 \% i tidsperioden 1956-1994, fra 2,7 til 13,8 per 100000 (Tondo \& Baldessarini 2001).

Ratene for sel vmordsforsøk er også svært urovekkende. Blant amerikanske elever på videregåen de skole (high school) finner man prevalenstall (noensinne har gjort selvmordsforsøk) som varierer mellom 3,5 \% og 11 \% (A ndrews \& Lewinsohn 1992). Det er beregnet at hvert år gjør mer enn 300000 ungdommer selvmordsforsøk av så stor alvorsgrad at medisinsk undersøkelse og/eller behandling er påkrevet (C enters for Disease C ontrol 1992). N esten 25 ganger dette antallet vil gjøre selvmordsforsøk som ikke krever medisinsk undersøkelse og/eller behandling. Selv om det er mange flere gutter enn jenter som tar sitt eget liv (King 1997), gjør jenter i ungdomsal deren 2-4 ganger så mange selvmordsforsøk (Lewinsohn et al. 1996). M ellom $31 \%$ og $50 \%$ av ungdom som gjør et selvmordsforsøk, gjør et nytt selvmordsforsøk senere (Shaffer \& Piacentini 1994), og mange av disse skjer innen de første tre månedene etter det første selvmordsforsøket (Lewinsohn et al. 1996).

Denne statistikken viser at det er et sterkt behov for effektive psykologiske intervensjoner, særlig fordi så mange som $50 \%$ av ungdom som har gjort et selvmordsforsøk, ikke mottar noen form for oppfølging innen psykisk helsevern (Spirito et al. 1989). 0 g opptil $77 \%$ av dem som faktisk får behandling, møter ikke jevnlig til avtaler eller fullfører ikke behandlingen (Trautman et al. 1993).

Fram til i dag har det bare vært gjennomført tre randomiserte og kontrollerte studier med suicidal ungdom som mål gruppe (Cotgrove et al. 1995, H arrington et al. 1998, W ood et al. 2001). Bare en av disse studiene demonstrerte en signifikant reduksjon i selvskadeatferd blant ungdom. I denne studien sammenlignet W ood et al. (2001) ordinær behandling (C are A s U sual/CAU ) med CAU pluss gruppeterapi med elementer hentet fra kognitiv atferdsterapi og dial ektisk atferdsterapi. Eksperimentgruppen ( $\mathrm{CAU}$ pluss gruppeterapi) hadde en signifikant større reduksjon i selvskadeatferd sammenlignet med den gruppen som bare mottok CAU .

$M$ ed utgangspunkt i pionerarbeidet til M arsha Linehan og kolleger (1991; 1993a; 1993b) som viste at dialektisk atferdsterapi (dialectical behavior therapy/DBT ) hadde effekt for suicidale voksne kvinner med diagnosen borderline personlighetsforstyrrelse, gjennomførte R athus og M iller (2002) en studie der en tilpasset variant av DBT ( M iller et al. 1997) ble sammenlignet med ordinær behandling (Treatment A s U sual/TAU ) overfor suicidal ungdom i et kvasi-eksperimentelt design. Resultatene fra denne studien indikerer at flere i DBT-gruppen $(n=29)$ fullførte behandlingen og færre ble innlagt i psykiatrisk sykehus mens behandlingen pågikk sammenlignet med TAU -gruppen ( $n=82$ ), på tross av at DBT-gruppen hadde fått påvist mer alvorlig symptomatologi før behandlingen (Rathus \& M iller 2002). Det var ingen signifikante forskjeller mellom gruppene i antallet selvmordsfors $\varnothing \mathrm{k}$ under behandlingen. $\mathrm{N}$ år man undersøkte endringer fra før til etter behandling $i$ DBT-gruppen, fant man signifikant reduksjon i selvmordstanker, generelle psykiatriske symptomer og symptomer på borderline personlighetsforstyrrelse.
M ed utgangspunkt i forskningen til Wood et al. (2001) og Rathus \& M iller (2002) ser det altså ut til at DBT-behandling eller behandling med elementer av DBT er den mest lovende form for behandling for suicidal ungdom og ungdom som gjentatte ganger utfører selvskadehandlinger når vi sammenlikner med annen publisert behandlingsforskning. Det er imidlertid behov for å få utført randomiserte kliniske studier før vi kan anbefale poliklinisk DBT og/eller den omtalte gruppebaserte behandlingsmodellen som førstevalget av mulige behandlingstiltak. I det følgende skal vi gi en kort oversikt over DBT med de kliniske tilpasninger som er gjort for suicidal ungdom, samt forskning som er gjort på området.

\section{Dialektisk atferdsterapi}

Dialektisk atferdsterapi (DBT) er en evidensbasert poliklinisk psykoterapi for kronisk parasuicidale kvinner med diagnosen borderline personlighetsforstyrrel se (BPD) (Linehan 1993a). Parasuicid er her definert som enhver akutt, intensjonell selvbeskadigen de handling med eller uten intensjon om å dø (Linehan 1993b). I en kontrollert behandlingsstudie som sammenliknet DBT med behandling som vanlig (TAU) for suicidale voksne pasienter, fant man at DBT mer effektivt reduserte sinne, selvmordsforsøk, andre parasuicidale handlinger, og antallet innleggel sesdøgn i psykiatrisk sykehus, samtidig som det var en bedring i sosial tilpasning, samarbeid om behandlingen og redusert frafallsprosent (Linehan et al. 1991). I en nyere studie fant Koons og medarbeidere (1998) at DBT var mer effektiv enn TAU i å redusere depresjon, håpløshet, selvmordstanker og sinne i en gruppe av voksne personer med BPDdiagnose.

DBT er basert på Linehans biososiale teori, der BPD primært blir betraktet som en dysfunksjon i det emosjonelle reguleringssystem (Linehan 1993a). Svikt i emosjonell regulering antas å være forårsaket 
av en negativ interaksjon mellom et individ som er biologisk predisponert for nettopp å ha slike vansker med å regulere emosjoner, og et miljø som intensiverer denne sårbarheten (Linehan 1993a). I følge teorien blir BPD-atferd resultatet når et barn som har vansker med emosj onell regulering, plasseres i et ikke-bekreftende miljø - et miljø som på en gjennomgripende måte kommuniserer til barnet at dets responser er upassende, feil, upresise eller på annen måte inadekvate ( $M$ iller 1999). I DBT anses suicidal- og selvdestruktiv atferd å ha viktige affektregulerende egen skaper i tillegg til at de tjener til å utløse hjelp fra et ellers ikke-bekreftende miljø (Miller et al. 1997). Basert på dette prinsippet er parasuicidale atferder forstått som maladaptive løsninger på overveldende, intenst smertefulle negative følelser.

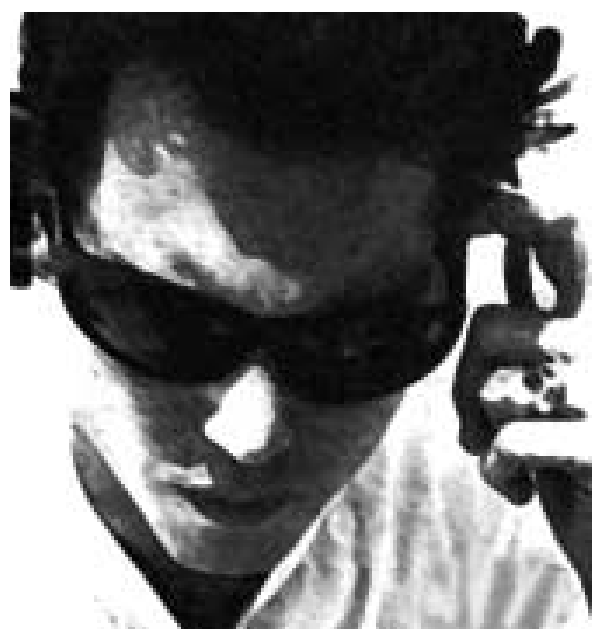

\section{Problemområder og tilsvarende ferdigheter}

Personer med BPD viser i typiske tilfeller funksjonssvikt på fem områder - emosjonell reguleringssvikt er det mest sentrale problemet (Linehan 1993a). Individer med BPD strever ofte med manglende kontroll over sinne og andre emosjoner, som igjen bidrar til problemer på fire andre områder: interpersonlig regulering, regulering av selvet, atferdsregulering og kognitiv regulering. Emosjonell ustabilitet kan forståelig nok bidra til manglende regulering av selvet ved forvirring når det gjelder selvforståelse og egne følelser. Kognitiv dysregulering, som f.eks. rigid tenkning og irrasjonelle forestillinger kan, i hvert fall delvis, forstås som en følge av emosjo- nell dysregulering. $M$ anglende evne til å regulere egen atferd, i form av impulsivitet og parasuicidal atferd, er vanlig, og kan være en konsekvens av emosjonell dysregulering eller et forsøk på å regulere følelser. D e problemområdene som Linehan i utgangspunktet tok for seg hos voksne, f.eks. emosjonell ustabilitet, impulsivitet, interpersonlige problemer og usikker selvoppfatning, har sterke fellestrekk med de utviklingsområdene som er svært sentrale i ungdomstiden ( M iller et al. 1997).

O pplæring i DBT-ferdigheter ble først utviklet av Linehan (1993b) og modifisert for ungdom (M iller et al. 1997), og tar for seg de fem problemområdene med korresponderen de moduler for atferdsmessige ferdigheter. K jerneferdighetsmodulen, "mindfulness", retter seg både mot den kognitive dysreguleringen og dysreguleringen av selvet. " $M$ indfulness"-ferdigheter ble utviklet på basis av meditasjonsøvelser hentet fra Ø sten (Linehan 1993a), og har som mål å hjelpe pasienter til å bevege seg vekk fra sin tendens til å ta valg på basis av ren emosjonalitet, over mot en integrering av både emosjonelle og rasjonelle in put, for å hjelpe dem til å ta balanserte, kloke ("wise mind") avgjørelser. Pasientene læres opp i ferdigheter til å observere og deretter beskrive sine egne interne opplevelser på en ikke-fordømmende måte. Dette hjelper dem i overgangen fra "emotional mind" til "wise mind". Etter fokusert bruk og trening av disse ferdighetene vil pasienter føle seg mer effektive i sine evner til å hanskes med vanskelige situasjoner. M odulen som fokuserer på ferdigheter i stresstoleranse (Distress Tolerance Skills M odule), retter seg mot impulsi vitet og problemer med å regulere egen atferd. Denne modulen inneholder både ferdigheter i å overleve kritiske situasjoner (f.eks. å distrahere seg selv, trøste seg selv, lage lister over argumenter for og mot) og ferdigheter $\mathrm{i}$ å godta selv ubehagelige kjensgjerninger. Stresstoleranseferdigheter hjel per pasienten til å tolerere tilsynelatende utolererbare situasjoner uten å "svare med" impulsive eller parasuicidale handlinger. M odulen som fokuserer på ferdigheter $\mathrm{i}$ følelsesregulering, Iærer pasienten hvordan det er mulig å redusere emosjonell sårbarhet, hvordan man kan handle mot-

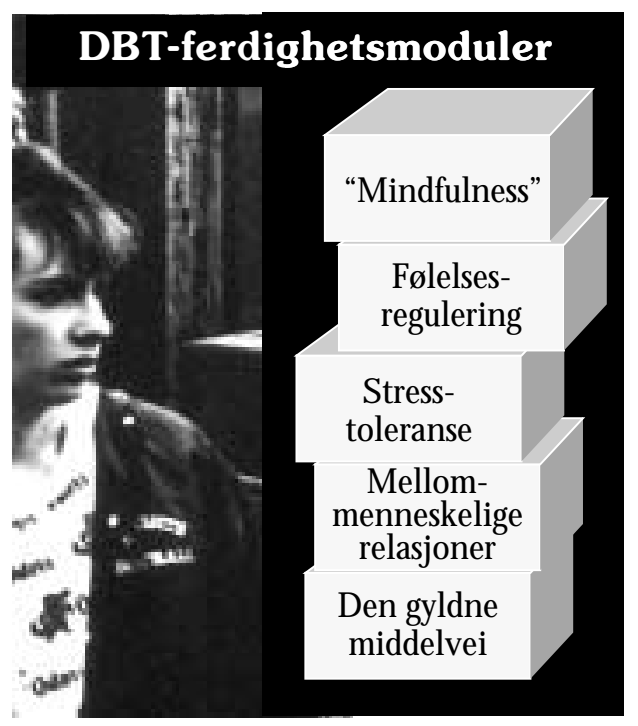

satt av de følelsene man har i øyeblikket, hvordan man kan redusere følelsenes intensitet, og øke positive erfaringer, og gjennom dette, positive følelser. M odulen som fokuserer på ferdigheter i mellommenneskelige relasjoner, lærer pasienter hvordan de kan forhandle med andre på en slik måte at de oppnår det de selv har behov for, samtidig som gode relasjoner bygges og selvrespekten opprettholdes (Linehan 1993a). Endelig har en tilleggsmodul blitt laget for suicidal ungdom og deres familier. Denne modulen kalles "Den gyldne middel vei" ( Walking the M iddle Path) (M iller et al. 2002). M odulen retter seg mot dial ektiske dilemmaer som oppstår innen familier, og visse dysfunksjonelle atferdsmønstre som dette kan resultere i. O ppgavene her er å finne en syntese mellom de eksisteren de ekstreme atferdsmønstrene, f.eks. overdreven ettergivenhet i motsetning til autoritær kontroll. Denne modulen fokuserer også på atferdsprinsipper og bekreftelse, som betraktes som ferdigheter som er helt avgjørende for at tenåringer og familiemedlemmer kan forbedre sine relasjoner.

\section{Behandlingens fem funksjoner}

Linehan (1993a) har beskrevet fem funksjoner i den behandlingen hun anbefaler for pasienter med BPD. Disse funksjonene former strukturen i DBT ved å

(1) fremme pasientens mestringsevner,

(2) styrke motivasjonen for endring,

(3) sikre at ny mestring generaliseres fra behandlingen til pasientens liv,

(4) fremme terapeutens evner og motivvasjon til å behandle pasienter effektivt, og

(5) strukturere miljøet slik at det støtter opp om pasientens og terapeutens mestring. 


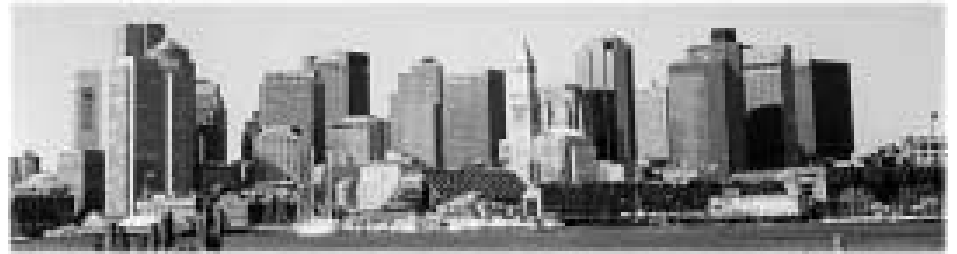

U like typer poliklinisk behandling ivaretar de fem funksjonene. En hovedterapeut sikrer at systemet som helhet oppfyller hver enkelt funksjon. U ngdommen og familien forplikter seg til å del ta i 16 ukers behandling, som består av ukentlig psykoedukativ ferdighetstrening i gruppe (Funksjon 1), og ukentlige samtaler med en individualterapeut for å identifisere og redusere faktorer som hemmer evnen til å bruke ferdighetene, og som bygger opp motivasjon til å bli bedre og til å forandre seg (Funksjon 2). I tillegg forplikter pasienten seg til å sikre overføring av ferdigheter fra behandlingssetting til eget liv ved telefonkonsultasjoner eller rettledning (coaching) i bruk av ferdigheter i krisesituasjoner (Funksjon 3). Terapeuten på sin side samtykker i å gi 16 ukers behandling. I denne perioden deltar han/ hun i ukentlige behandlermøter, der det gis både metodisk og emosjonell støtte til terapeuten (Funksjon 4). Endelig samtykker terapeuten i å stille opp med eventuelle tilleggsintervensjoner som kan bli nødvendige for å strukturere miljøet slik at pasienten ikke trenger å bli verre for å få ekstra hjelp, eller eventuelt forholde seg til temaer som har med pasientens familie å gjøre (Funksjon 5) (Rathus \& M iller 2002, M iller 1999, Katz et al. 2002b, Miller et al. 2002).

De primære fokus for behandlingen er de målsettinger som skal oppnås før behandlingen igangsettes (enighet om mål og forpliktelse til endring), og mål settinger for første trinn i behandlingen (sikkerhet, stabilitet, atferdskontroll og fremming av grunnleggende ferdigheter) (M iller 1999). Individualterapeuten gjør bruk av DBT-strategier i forhold til den målsetting som har høyest prioritet i øyeblikket. H vert steg $\mathrm{i}$ behandlingen er strukturert for å sette fokus på følgende spesifikke områder (hierarkisk etter ansett betydning):

(1) livstruende atferd,

(2) atferd som interfererer med behandlingen,

(3) atferd som står i veien for god livskvalitet, og

(4) økning av atferdsmessige ferdigheter.

Eksempelvis vil det alltid være slik at dersom en parasuicidal handling skjer mellom terapisesjonene, vil denne handlingen være det primære fokus for samtalen.

\section{DBT med ungdom}

DBT ble tilpasset til bruk for suicidal ungdom med borderline personlighetstrekk på grunn av metodens spesifikke fokus på reduksjon av suicidal atferd og atferd som står i veien for livskvalitet, i tillegg til metodens evne til å fastholde de unge pasientene tilstrekkelig lenge i behandlingen (M iller 1999). DBT gir struktur til behandlingen. $\mathrm{H}$ ierarkiet av behandlingsmål er en hjelp til å identifisere hva som er det passen de problemområdet å fokusere på til enhver tid. M odellens mange innfall svinkler innebærer en fleksibilitet i å nærme seg de multiple problemene disse ungdommene har. I tillegg fokuserer DBT spesielt på atferd som interfererer med behandlingen.

Det er flere forskjeller mellom DBT til ungdom og DBT til voksne. Først og fremst ble behandlingsvarigheten redusert fra ett år til 16 uker. Dette ble gjort både fordi det var et større behov for kortvarig behandling, og fordi ungdom i mindre grad enn voksne har utviklet kroniske symptomer (Rathus \& M iller 2000). For det andre blir foreldre inkludert i ferdighetstreningsgruppen. Dette bedrer sjansen for general isering og opprettholdelse av ferdigheter gjennom at familiemedlemmer lærer de nye ferdighetene, og at ungdommens ofte dysfunksjonelle og ikkebekreftende hjemmemiljø bedres ( $M$ iller et al. 1997). En tredje forskjell er at DBT til ungdom også inkluderer familieterapi (M iller et al. 2002). For det fjerde har antallet ferdigheter som skal læres blitt redusert, og språket i ferdighets-han doutene har blitt forenklet slik at det passer bedre til brukernes utviklingstrinn og subkulturelle særtrekk. Endelig ble en helt ny ferdighetstreningsmodul lagt til behandlingsmetoden. H ensikten med denne var å lære atferdsprinsipper og bekreftelse, og å sette fokus på dial ektiske dilemmaer i interaksjonen mellom ungdom og foreldre (Rathus \& M iller 2000).

Inklusjonskriterier for ungdom til et poliklinisk DBT-program består av:

1) alder 13 til 19 år (både gutter og jenter),

2) parasuicidal atferd de siste 16 ukene eller nåværende suicidal tanker og

3) BPD-diagnose eller BPD-trekk (definert etter SCID-II).
Eksklusjonskriterier består av: mental retardasjon, psykotisk lidelse, bi polar lidelse, eller alkohol/stoffavhengighet/misbruk som primær diagnose.

Etter at programmet på 16 uker er fullført, får pasienter og deltaken de familiemedlemmer et diplom under en høytidelig avslutningsseremoni. Individual terapien er da avsl uttet, men ungdom får muligheten til å delta i en ny 16-ukers "pasientkonsultasjonsgruppe" (også kalt "the graduation group") sammen med andre ungdommer som også har full ført programmet. U ngdommene møtes hver uke i en og en halv time for å "rådslå" om hvordan de effektivt kan gjøre bruk av sine nye ferdigheter for å mestre aktuelle livsproblemer (M iller et al. 1997, M iller 1999). Denne gruppen hjel per tenåringene til å forsterke og general isere sine ferdigheter samtidig som et nytt kameratstøttenettverk kan dannes. I tillegg skal denne "pasientkonsultasjonsgruppen" bidra til à redusere pasientens avhengighet av sin terapeut og fremme ungdommenes evne til å hjel pe hverandre.

\section{Nyere forskning}

I tillegg til den tidligere nevnte studien av Rathus og M iller (2002) gjorde M iller og medarbeidere i 2000 en undersøkelse av hvilke atferdsmessige ferdigheter som ble brukt mest av suicidal ungdom som fikk dial ektisk atferdsterapi. I denne studien ga ungdommene sine egne vurderinger av nytten av de forskjellige DBTferdighetene, i tillegg til at effektiviteten av DBT-behandlingen ble evaluert før og etter behandling. I tråd med tidligere forskning viste studien signifikant reduksjon i BPD-symptomer på alle fire problemområder, dvs. impulsivitet, emosjonell ustabilitet, intensitet i problemer og forvirring i selvoppfatningen. De fire ferdigheter som ble vurdert som mest nyttige, inkluderte stresstoleranse og "mindfulness".

I en nyere undersøkelse tilpasset $\mathrm{Katz}$ og medarbeidere (2002a) ungdoms-DBT til suicidale pasienter som var innlagt $\mathrm{i}$ psykiatrisk sykehus. Denne studien er den første som undersøker effekten av et toukers D BT-program for innlagte suicidale ungdommer sammenliknet med ordinær behandling (TAU). DBT-programmet bestod av en times daglig ferdighetstrenings- 
gruppe der man gjennomgikk "lekser" (treningsoppgaver) i tillegg til at man lærte nye ferdigheter i "mindfulness", stresstoleranse og emosjonell regulering. Individuell psykoterapi ble gitt to ganger i uken, og i disse samtalene gikk man gjennom dagbøker, utførte atferdsanalyser og tok opp individuelle tema. I tillegg skapte personalet på avdelingen et DBT-miljø for å fremme ferdighetsgeneralisering.

TAU besto av en daglig psykoterapigruppe, individuell psykoterapi og et psykodynamisk orientert avdelingsmiljø. R esultatene indikerte at DBT-gruppen $(n=18)$ hadde signifikant færre vanskelige episoder på avdelingen av typen angrep på personale eller andre pasienter eller selvbeskadigelse, sammenliknet med TAU gruppen $(n=12)$. Ingen medlemmer $\mathrm{i}$ DBT-gruppen gjorde noen selvskadehandlinger, og alle pasientene som ble inkludert i DBT-gruppen, fullførte programmet. Selv om disse resultater er lovende, er det nødvendig å følge opp med evalueringer seks måneder og ett år etter avsluttet behandling.

For å oppsummere er det rimelig å si at dialektisk atferdsterapi tilpasset ungdom i flere forskjellige behandlingssituasjoner har vist seg å være en lovende behandlingsform for parasuicidal ungdom med BPD-diagnose eller med borderline personlighetstrekk. Forståel sen av selvmord, selvmordshandlinger og selvmordstanker blant ungdom er et fagfelt i behov av videreutvikling. Det er et stort behov for randomiserte kliniske studier i alle behandlingssettinger for å fremme vår forståel se av hvorvidt DBT til ungdom er en egnet og kostnadseffektiv behandling. 0 mråder som bør få klinisk og forskningsmessig oppmerksomhet gjennom denne metodeutviklingen, er relasjonen mellom familie terapi og DBT med ungdom i tillegg til bruk av DBT i skolen. M ed utgangspunkt i sekundærforebygging i skolen kan DBT være en profylakse for BPD og parasuicid. Tidlig intervensjon kan trolig hindre utviklingen av parasuicid og av en manifest personlighetsforstyrrelse. Som kliniske forskere må vi være utholden de i våre bestrebelser på å gjennomføre slik krevende forskning dersom vi har til hensikt å redusere sykelighet og dødelighet hos risikoungdom.

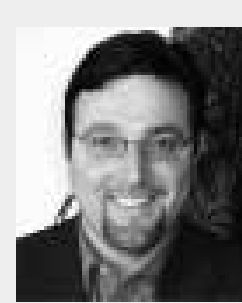

A lec Miller (PsyD) er A ssociate professor i psykiatri ved A lbert Einstein College of M edicine i $N$ ew York og leder for Barne- og ungdomspsykiatrisk enhet ved $M$ ontefiore M edical C enter samme sted. M iller har siden 1995 ledet et forskningsklinisk team som har utviklet en tilpasset utgave av DBT for suicidal og deprimert ungdom. $\mathrm{H}$ an har holdt en rekke seminarer om DBT både nasjonalt og internasjonalt, og har skrevet flere viten skapelige artikler.

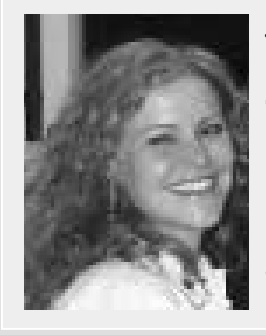

Jennifer $\mathrm{H}$ artstein er psykol og og doktorgradsstipendiat i klinisk barnepsykologi. H un har p.t. praksis ved $M$ ontefiore $M$ edical $C$ enter, hvor hun er med i DBT-behandlingen av suicidal ungdom og deres familier.

A rtikkelen er oversatt av Siri T horesen

\section{Referanser}

A merican $A$ cademy of $C$ hild and $A$ dolescent Psychiatry. Teen Suicide-A A C A P Facts for Families \#10. 1998. A vailable from the A merican A cademy of C hild and A dolescent Psychiatrywww.aacap.org/publications/factsfam/suicide.htm

A ndrews JA, Lewinsohn PM .Suicidal attempts among older adolescents: prevalence and cooccurrence with psychiatric disorders. J A $m$ A cad $C$ hild A dolesc Psychiatry $1992 ; 31(4)$ : 655-62.

$C$ enters for Disease $C$ ontrol and Prevention. $B$ ehaviors related to unintentional and intentional injuries among high school students - U nited States, 1991. M orbidity and M ortality W eekly Report 1992; 41: 760-772.

C otgrove A J, Zirinsky L, BlackD , \& W eston D. Secondary prevention of attempted suicide in adolescents. Journal of A dolescence 1995; 18: 569-577.

H arrington $R$, Kerfoot $M$, Dyer $E, M C N$ iven $F, G$ ill J, H arrington V, Woodhan A \& Bedford S. R andomized trial of a home-based family intervention for children who have deliberately poisoned themselves. Journal of the A merican A cademy of C hild and A dolescent Psychiatry 1998; 37: 512-518.

H olinger PC, O ffer D, Barter JT \& Bell, CC Suicide and homicide among adolescents. $\mathrm{N}$ ew York: G uilford Press, 1994.

Katz LY, G unasekara S, C ox BJ \& M iller A L. Effectiveness of dialectical behavior therapy for inpatient suicidal adolescents. In press (2002a)

Katz LY, G unasekara $S \&$ M iller A L. D ialectical behavior therapy for inpatient and outpatient suicidal adolescents. A nnals of A dolescent Psychiatry 2002b; 26: 161-178.

King CA, H ovey JD, Brand E, Wilson R, G haziuddin N . Suicidal adolescents after hospitalization parent and family impacts ontreatment followthrough. J A m A cad C hild A dolesc Psychiatry 1997 Jan;36( 1):85-93.
Koons CR., Robins CJ, Bishop GK, M orse JQ, Tweed JL, Lynch TR G onzalezA M. Efficacy of dialectical behavior therapy with borderline women veterans: $\mathbf{A}$ randomized controlled trial. Paper presented at the annual meeting of the A ssociation for the A dvancement of Behavior Therapy, W ashington DC 1998, N ovember.

Lewinsohn PM, Rohde P\& SeeleyJR. A dolescent suicidal ideation and attempts: Prevalence, risk factors, and clinical implications. Clinica Psychology Science and Practice 1996; 3: 25-46.

Linehan M M . C ognitive behavioral treatment of borderline personality disorder. N ew York: G uilford Press, 1993a.

Linehan M M . Skills training manual for treating borderline personality disorder. N ew York: G uilford Press, 1993b.

Linehan $M M$ M A rmstrong $H E$, Suarez $A$, A llmon $D \& H$ eard $H L$. C ognitive-behavioral treatment of chronically parasuicidal borderline patients. A rchives of G eneral Psychiatry 1991; 48: 10601064

M iller A L. Dialectical behavior therapy: A new treatment approach for suicidal adolescents. A merican Journal of Psychotherapy 1999; 53 (3) 413-417.

Miller $A L \&$ G linski I. Youth suicidal behavior: A ssessment and intervention. Journal of Clinical Psychology 2000; 56(9): 1131-1152.

Miller A L \& RathusJ. Dialectical behavior therapy: A daptations and new applications. Cognitive and Behavioral Practice 2000; 7: 420-425.

Miller A L, Rathus IH, Linehan M M , W etzler S \& Leigh $E$. D ialectical behavior therapy adapted for suicidal adolescents. Journal of Practical Psychology and Behavioral $H$ ealth 1997: 78-86.

Miller A L, W yman SE, G lassman SL, H upper JD $\&$ Rathus $J$. A nalysis of behavioral skills utilized by adolescents receiving $D$ ialectical $B$ ehavior Therapy. C ognitive and Behavioral Practice 2000; 7: 183-187.

Miller A L, Glinski J, Woodberry K, Mitchell A \& Indik J. Family therapy and dialectical behavior therapy with adolescent: Part 1, Proposing a clinical synthesis. A merican Journal of Psychotherapy 2002; 56(4): 1-17.

$\mathrm{N}$ ational $\mathrm{C}$ enter for $\mathrm{H}$ ealth Statistics. A dvance report of final mortality statistics, 1994. N ational M onthly Vital Statistics Report 1996; 45(63).

Peters KD, Kochanek KD \& M urphy SL. D eaths: Final data for 1996. N ational Vital Statistics Report 1998; 47(9).

Rathus JH \& Miller A L. Dialectical behavior therapy adapted for suicidal adolescents. Suicide and Life-Threatening Behavior 2002; 32: 146-157.

Rathus JH \& Miller A L. DBT for adolescents:

Dialectical dilemmas and secondary treatment targets. Cognitive and Behavioral Practice 2000; 7: 425-434

Satcher D. D epression and suicide in children and adolescents. In M ental $\mathrm{H}$ ealth: A R eport of the Surgeon $G$ eneral. 2000. A vailable at: www.surgeongeneral.gov/library/mental health/c hapter3/sec5.html.

Shaffer D \& Piacentini J. Suicide and suicide attempts. In M. Rutter, L. H ersov \& E. Tayl or (Eds.) C hild and A dolescent Psychiatry, 3rd edition London: Blackwell Scientific Publications, 1994 


\section{Tverrfaglighet er ønskelig}

For egen del vil jeg si at i utarbeidelsen av kurskonseptet ligger det som en viktig, men ikke absolutt nødvendig premiss at kurset skal være tverrfaglig sammensatt. 0 ptimale læringsbetingelser oppnås når deltakerne representerer ulike befolkningsgrupper og kulturer. Fra en kursleder med noe erfaring er det fristen de å legge til at det i møtet mellom forskjellige yrkeskulturer ofte oppstår spennende utfordringer som også bidrar til å bryte ned barrierene og revirtenkningen gruppene i mellom. Som et eks. på dette kan jeg vise til at politifolk ofte fremstår som svært handlingsorienterte i møtet med selvmordstruede mennesker. For mange kursdeltakere er dette en positiv overraskelse og bidrar til å øke læringsutbyttet for alle. Førstehjelp ved selvmordsfare dreier seg nettopp om å intervenere raskt slik at liv ikke går tapt. Det er for øvrig et prinsipp som gjelder all førstehjelp. Selvmordsatferd representerer ingen unntak fra denne regelen.

(Dag W illy Tallaksen er undervisningskonsulent ved SSF F.)

Forts. fra s. 12 (- M ehlum)

G laser D. C hild abuse and neglect and the brain - a review. J Child Psychol Psychiatry 2000; 41(8): 1076.

Isometsä ET. Psychological autopsy studies - a review. Eur Psychiatry 2001;16 (7): 379-85.

Kaplan JR, M uldoon M F, M anuck SB, M ann JJ. A ssessing the observed relationship between low cholesterol and violence-related mortality. I mplications for suicide risk. A nn N Y A cad Sci 1997; 29 (836): 57-80.

Linnoila $M$, Virkkunen $M$, Scheinin $M, N$ uutila $A$, Rimon R, Goodwin FK. Low cerebrospinal fluid 5-hydroxyindoleacetic acid concentrations differentiates impulsive from non-impulsive violent behavior. Life Sciences 1983; 33(26): 2609-14.

LopezJF, Vazquez DM , Chalmers DT, W atson SJ. R egulation of 5-H T receptors and the hypothalamic-pituitary-adrenal axis. Implications for the neurobiology of suicide. A nn N Y A cad Sci 1997; 29(836): 106-34.

M ann JJ, A rango $V$. N eurobiology of suicidal behavior. I: W asserman D (ed). Suicide - an unnecessary death. London: Dunitz, 2001.

$M$ CG uffin $P$, M arusic A, Farmer $A$. What can psychiatric genetics offer suicidology? C risis 2001; 22(2): 61-5.

$N$ ielsen $D, G$ oldman $D$, Virkkunen M, Tokola R Rawlings R, Linnoila M. Suicidality and 5-hydro- xyindoleacetic acid concentration associated with a tryptophane hydroxylase polymorphism. A rch G en Psychiatry 1994; 51: 34-8.

N ordström P, Samuelsson M, A sberg M , TräskmanBendz L, A berg-W istedt A, N ordin C, Bertilsson L. C SF 5-H IA A predicts suicide risk after attempted suicide. Suicide \& Life-threatening Behav 1994; 24: 1-9.

0 'Keane V, Dinan T G. Prolactin and cortisol responses to $D$-fenfluramin in major depression evidence for diminshed responsivity of central serotonergic function. A m J Psychiatry 1991; 148 1009-15.

Plotsky PM, O wens M J, N emeroff C B. Psychoneuroendocrinology of depression. $H$ ypothalamicpituitary-adrenal axis. Psychiatr C lin N orth A m 1998; 21(2): 293-307.

Roy A, Segal N, C enterwall D, Robinette D.

Suicide in twins. A rch G en Psychiatry 1991; 48: 29-32.

Roy A, Segal N, Sarchiapone M. A ttempted suicide among living cotwins of twin suicide victims. A m J Psychiat 1995; 152: 1075-6.

Van Praag H M, Korf J, Puite J. 5-hydroxyindoleacetic acid levels in the cerebrospinal fluid of depressive patients treated with probenecid. N ature 1970; 225: 1259-60.

W ender $P$, K ety $S$, R osenthal D, Schulsinger $F$, Ortmann J, Lunde I. Psychiatric disorders in the biological and adoptive families of adopted individuals with affective disorders. A rch $G$ en Psychiatry 1986; 43: 923-9.

A sberg M, Träskman L, Thorén P. 5-HIA A in the cerebrospinal fluid: A biochemical suicide predictor. A rch G en Psychiatry 1976; 33: 1193-7.

Forts. fra S. 10 (- M iller og H artstein)

Shaffer D, G ould M \& HicksR. W orsening suicide rate in black teenagers. A merican Journal of Psychiatry 1994; 151: 1810-1812.

Shaffer $D \& H$ icks R. T he epidemiology of child and adolescent suicide. In B.Pless (Ed.), The Epidemiology of $C$ hildhood Disorders. N ew York: Oxford U niversity Press, 1993.

Spirito A, Brown L, O verholser J \& Fritz G . $A$ ttempted suicide in adolescence: $A$ review and critique of the literature. C linical Psychology Review 1989; 9: 335-363.

Sunseri PA. Preliminary outcomes on the use of D ialectical Behavior T herapy to reduce hospitalization among adolescents in residential care. In press. 1-26. (2002)

Tondo L \& Baldessarini RJ. Suicide: A n overview. Psychiatry Clinical M anagement 2001; 3: 1-36.

Trautman $\mathrm{P}$, Stewart $\mathrm{N} \& \mathrm{M}$ orishima $\mathrm{A}$. A re adolescent suicide attempters non-compliant with outpatient care? J ournal of the A merican A cademy of $C$ hild and A dolescent Psychiatry 1993; 32: 89-94

Wood A, Trainor G, Rothwell J, M oore A \& $H$ arrington $R$. R andomized trial of group therapy for repeated deliberate self-harm in adolescents. Journal of the A merican A cademy of $C$ hild and A dolescent Psychiatry 2001; 40: 1246-1253.
Forts. fra s. 15 (- G jertsen)

Simpura J, Levin BM . D emystifying R ussian drinking. A $\mathbf{n}$ introduction. In: Simpura $\&$ Levin BM (eds). Demystifying Russian D rinking. Comparative Studies from the 1990s. STA KES, Research Report 85. H elsinki, 1997.

Thelle DS. D ødelighetsutviklingen i R ussland. Tidsskr N or Lægeforen 1999; 119: 1482-4.

U.S. C ensus Bureau, International Programs $C$ enter. $C$ ensus dates for countries and areas of the world: 1945 to 2004. Last revised $15 \mathrm{~A} \mathrm{ug}$ 2001. http://www.census.gov/ipc/www/cendates/

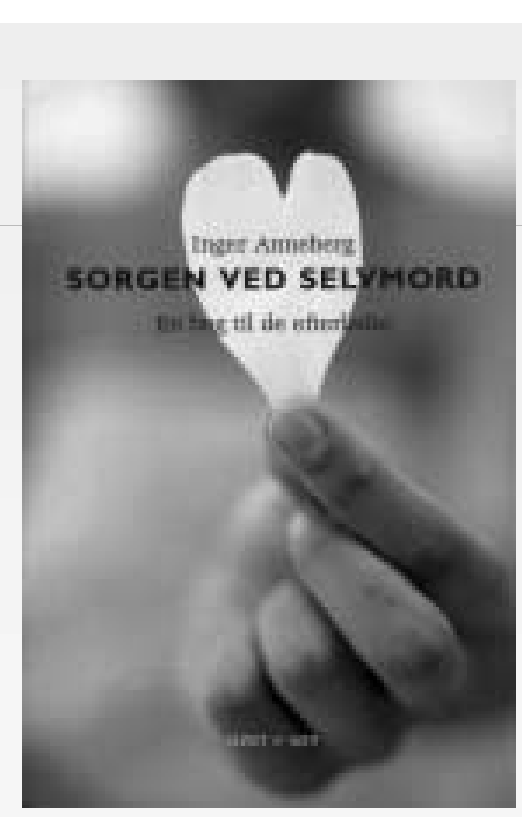

A nneberg, Inger

Sorgen ved selvmord: en bog til de efterladte.

København: Høst \& Søn, 2002.

$-373 \mathrm{~s}$.

ISBN 87-14-29766-3

"D enne bog er skrevet med ét formål: A t give mæle til mennesker, der ofte bliver mødt med tavshed." Slik åpner A nneberg sin bok der hun har intervjuet mange mennesker som har opplevd at en som stod dem nær, døde ved selvmord. Barn og voksne forteller om sine erfaringer og overlevelsesstrategier. Fagfolk er også intervjuet. 